\title{
Work Commitment as a Mediator of Work Environment Effect on Employee Performance
}

\section{Elly Wahyu Hidayati}

State Islamic University of Maulana Malik Ibrahim Malang, Indonesia.

\section{Achmad Sani Supriyanto} State Islamic University of Maulana Malik Ibrahim Malang, Indonesia.

Vivin Maharani Ekowati* State Islamic University of Maulana Malik Ibrahim Malang, Indoneesia.

vivien.maharani@yahoo.com

${ }^{*}$ Corresponding author

\begin{abstract}
Human resource management plays as a prominent element in achieving an organizational goal. Therefore, an organization needs to provide a positive guide to achieve the organizational goals. It is supposed to be aware of the importance of human resources in the current global era by improving their quality that their performance increases. This study aims to examine the effect of work environment on work commitments, work commitment on employee performance, and work commitment as a mediator of work environment influence on employee performance. The samples are 43 KPPN employees in Malang. Data are collected directly from the respondents through questionnaires and analyzed with path analysis using SPSS software. The result shows that work environment has a positive and significant influence on work commitment, and work commitment also has a positive and significant effect on employee performance. Therefore, work commitment proves to be a mediating variable.
\end{abstract}

Keywords: Work Environment, Employee Performance, Work Commitment.

\section{INTRODUCTION}

Human resource management plays as a prominent element in achieving an organizational goal (Cintia and Gilang, 2016). Therefore, an organization needs to provide a positive guide to achieve the organizational goals. It is supposed to be aware of the importance of human resources in the current global era by improving their quality that their performance increases (Supriyanto et al., 2020).

Basically, company's performance is related to human resources with their capability to adapt with the continous environmental change. One of the factors that affects the employee performance is work environment (Wijayanti \& Susanti, 2017). Robbins (2006) reveals that an organizational ability to survive is dependent on whether it can adapt with the environmental changes. An organization should adapt with the environment to stay competitive because the success of the organization is basically determined by the employee contribution, organizational changes, and work environment (Robbins, 2006). 
In addition to the work environment, it is also supported by the employee commitment. Organizational commitment is influenced by the environment where the employees work. If the work environment is not comfortable, for example lack of facilities, the employment relationship will find less harmony and social security, which automatically fades their commitment to the organization (Shalahudin, 2013).

The effect of work environment on employee performance has been studied by several researchers, such as Moulana, Sunuharyo \& Utami (2017), Setiawan \& Lestari (2016) who denotes that it can provide a positive and significant influence to the employee performance. Alzghoul et al. (2018) (Jayaweera, 2015; Narasuci, 2018; Samson et al., 2015) also states that it can improve the performance of the employees. According to Jerry et al. (2012), there is a direct relationship between work environment and employee performance.

Some previous researchers also examine the influence of work environment on employee commitment, for example Putri (2014) who reveals that a conducive working environment can foster employee commitment. The research of Nadia and Fathurahman (2017) concludes that work environment can enhance employee commitment. Also, Triwahyuni and Ekowati (2017) find that commitment has significant influence on performance. This study is conducted based on the gap of a research by Putri et al. (2019) by exploring and identifying the model of a causal work commitment as the mediating variable. In this study, we introduce employee work environment and its relationship with work commitment to improve employee performance. To generate an empirical contribution, this study aims to find out whether work environment increases work commitment, whether work commitment can improve the employee performance, and whether work commitment mediates the variables.

\section{LITERATURE REVIEW}

\section{Work Environment}

Work environment is a psychological environment of employees within an organization and is considered to affect their attitude and behavior towards their work (Shalahudin (2013). Gitosudarmo (2000) states that work environment is everything around the employees that can affect their work motivation, such as lighting, noise control, cleanliness, and the security. A conducive working environment providing a safe and comfortable employee can lead them to work more optimally.

\section{Employee Performance}

Performance is a work result that can be achieved by a person or group of people in an organization, according to their respective authority and responsibility, to achieve the organizational goal legally, following the law, moral, and ethic (Prawirosentono, 1999). Mangkunegara (2002) reveals that performance is a work result in quality and quantity by the employees when they have accomplished the task based on their responsibility. 


\section{Work Commitment}

Putri (2014) mentions that, commitment is an employee's feeling of identification, loyalty, and involvement towards the organization or organizational unit. Commitment to the organization involves three attitudes: (1) a feeling of identification towards the organizational goals; (2) involvement in the organizational task; and (3) loyalty to the organization. Work commitment is related to the definition of the organizational members to their work and the way they carry out their duties within the organization. It refers to a psychological state that binds the individual to the organization (Allen and Meyer 1990).

\section{The Relationship Among Variables}

Working environment refers to the things around the workers that can affect them upon finishing the tasks given (Nitisemito 2015). Shalahudin (2013) reveals that a company should create a comfortable work environment to improve the employee's work commitment. Likewise, a research by Putri (2014) finds out that a conducive work environment can foster employee commitment.

H1: Work Environment (X) affects on Commitment ( $\mathrm{Z}$ )

Commitment refers to a psychological state that binds individuals to the organization (Allen and Meyer 1990). Organizational commitment is an important aspect that needs to be on the concern of the company because it is closely related to the employee performance. An employee who has a strong organizational commitment will perceive that both personal and company goals are personal and need to fight for (Ivancevich, et al., 2011). Employees who have a strong commitment will make every possible effort to achieve the company goals, that it also affects the work results either in quality or quantity (Sutanto and Ratna, 2015). Also, Triwahyuni and Ekowati (2017) find that commitment has significant influence on performance. Nadia and Fathurahman (2017) reveal that environment can enhance employee commitment. While Sudibjo \& Nasution (2020); Cintia and Gilang (2016) explain that physical and non-physical work environments affect the employee performance. Thus, this research proposes that:

H2: Commitment ( $\mathrm{Z}$ ) effects on Employee Performance $(\mathrm{Y})$.

H3: Commitment $(Z)$ mediates the influence of Work Environment $(X)$ on Employee Performance $(\mathrm{Y})$.

\section{Hypothesis Model}

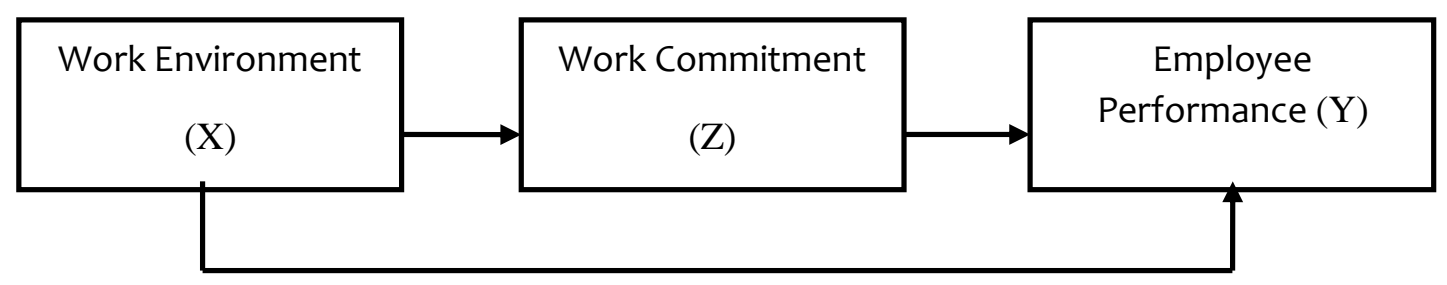

Figure 1. Hypothesis Model 


\section{METHODOLOGY}

This study employs a survey research method with quantitative approach. It is conducted in the Office of State Treasury Services (KPPN) Malang located at Merdeka Selatan Street, No. 1-2, Kiduldalem, Klojen, Malang. The research subjects the overall employees of KPPN Malang with 43 members. The measurement tool of this research is a questionnaire. There are primary and secondary data, which are analyzed by using path analysis. Path analysis is used to describe the relationship of an independent variable with a dependent variable either directly or indirectly (Supriyanto and Ekowati, 2019). The independent variable in this study is work environment. The indicator of work environment refers to the view of Sedarmayanti (2009), covering physical and nonphysical work environment. The dependent variable in this study is employee performance, refering to Dharma (1991), covering Quantity, Quality, Punctuality. The mediation variables is work commitment, which according to Allen and Meyer (1990) consists of organizational goals; (2) a feeling of involvement in the organization task; and (3) loyalty to the organization.

\section{RESEARCH RESULTS}

\section{Hypothesis Testing}

The decision making of the hypothesis testing employs a comparison of $t$ statistic value with the $t$ table value, whose $t$ statistics value is greater than $t$ table value, which is 1,96 indicating a significant effect. The result of the hypothesis is provided in the following Table 1.

Table 1. Hypothesis Testing

\begin{tabular}{clccll}
\hline Hypothesis & Influence & Coefficient & t Statistics & Significance & Description \\
\hline 1 & $\mathrm{X} \rightarrow \mathrm{Z}$ & 0,801 & 8,564 & 0,000 & Significant \\
2 & $\mathrm{Z} \rightarrow \mathrm{Y}$ & 0,327 & 2,451 & 0,019 & Significant \\
3 & $\mathrm{X} \rightarrow \mathrm{Z} \rightarrow \mathrm{Y}$ & 0,189 & 3,490 & 0,000 & Significant \\
\hline
\end{tabular}

The test result in Table 1 shows that the value of the t statistics is 8,564, greater than that of $t$ table, which is 1,96 . Therefore, it concludes that work environment influences work commitment. The $t$ value in the path of work commitment to the employee performance is 2,451 , which is greater than 1,96 ; so it concludes that work commitment affects the employee performance. It also happens in the path of work environment, that the $t$ count value of work commitment on employee performance is 3,490 , which is greater than the $t$ table value 1,96 . It concludes that work commitments mediates the effect of work environment on employee performance.

\section{Path Analysis}

This research employs path analysis, This Model is used to analyze the relationship pattern among variables, which aims to determine the direct or indirect influence of a

62 Management and Economics Journal (MEC-J)

Vol 5 (1) April 2021 
set of independent variables (exogenous) on the dependent variable (endogenous) (Supriyanto and Maharani, 2019). Path analysis tests the influence among variables, which consist of work environment, employee performance, and work discipline. The development of the pathway diagram can be described as Figure 2.

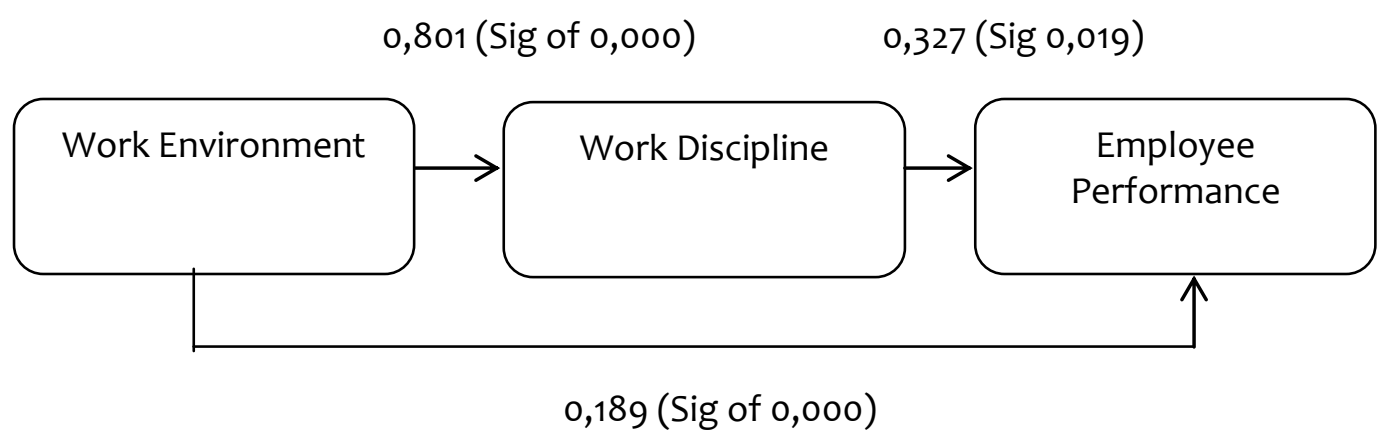

Figure 2. The Development of Pathway Diagram

\section{Test of Mediation}

Mediation testing aims to detect the position of the intervening variable in the model. Hypothesis testing of mediation can be performed through Sobel Test by using Free Statistic Calculation software for Sobel Test version 4.0. To test the significance of the indirect effect, it is necessary to test the $t$ value of the coefficient $a b$. The value of $t$ count is compared with that of the $t$ table. If the value of $t$ count $>t$ table, the influence of mediation occurs (Ghozali, 2013). The result of the Sobel test is 2,136 $\geq 1,96$. It concludes that work commitment mediates the effect of work environment on employee performance.

\section{DISCUSSION}

The result of the research shows that work environment has a significant influence on work commitment. The better the work environment is, the better the employee commitment will be. On the contrary, if the work environment is not good or not comfortable, the work commitment may decrease. This is in line with the research results conducted by Putri (2014) that work environment influence work commitment. Shalahudin (2013) reveals that organizational commitment is also influenced by work environment, that to increase the employee commitment, the company should create a comfortable working environment. If the work environment is not comfortable, the employee commitment to the organization will automatically be faded Shalahudin (2013).

Work environment has a significant influence on work commitment. The finding goes in line with the view of Triwahyuni and Ekowati (2017), that commitment has a significant influence on performance. An employee who has a strong organizational commitment will perceive that both personal and company goals are personal and need to fight for (Ivancevich, et al., 2011). Employees who have a strong commitment will make every 
possible effort to achieve the company goals, that it also affects the work results either in quality or quantity (Sutanto and Ratna, 2015).

The research concludes that work commitment mediates the influence of work environment on employee performance. The finding is in line with the research result by Nadia and Fathurahman (2017), which reveals that work environment can enhance employee commitment. Also, Triwahyuni and Ekowati (2017) find that commitment has significant influence on performance. The finding goes in accordance with the research result by Robbins (2006), the development of an organization is dependent on its ability to adapt with the environmental changes. An organization should adapt with the environment to stay competitive. Furthermore, Sedarmayanti (2009) notes that work environment affects employee performance. Therefore, a conducive working environment is needed to support the employee performance, so the work can be optimally accomplished.

\section{CONCLUSION}

Work environment influences Work Commitment. A good working environment can lead to an increase in the work commitment of the employees that high achievement can be reached. Work commitment affects the employee performance, evidenced by the fact that it is closely related to the ability of the employees to adapt with any conditions that can increase their performance. Work commitment mediates the effect of work environment on employee performance. We need work commitment to improve the employee performance. It mediates the effect of work environment on employee performance in KPPN Malang. Finally, we suggest that the organization needs to concern on work environment and employee commitment to improve the employee performance. Further researches are expected to expand the research orientation by adding moderating variables, so the research becomes broader.

\section{REFERENCES}

Alzghoul, A., Elrehail, H., Emeagwali, O., \& Aishboul, M. (2018). Knowledge Management, Workplace Climate, Creativity, And Performance: The Role Of Authentic Leadership. Journal of Workplace Learning, 30(8),592-612. https://doi.org/10.1108/JWL-12-2017-0111

Allen, Nathali J dan Meyer, Jhon P. (1990). The Measurement and Antecedents of Affective, Continuance and Normative Commitment to The Organization. London: The Journal of Occupational Phsychology, 1990(63), 1-18.

Cintia, E., Gilang, A. (2016). Pengaruh Lingkungan Kerja Fisik dan non Fisik terhadap Kinerja Karyawan KPPN Bandung. Jurnal Sosioteknologi, 15(1), 136-154.

Dharma, A. (1991). Manajemen Prestasi Kerja. Jakarta: PT. Rajawali.

Ghozali, I. (2013). Aplikasi Analisis Multivariate dengan Program IBM SPSS 21. Semarang: Universitas Diponegoro. 
Gitosudarmo, I, (2000). Manajemen Sumberdaya Manusia. Yogyakarta: Gajah Mada University Press.

Ivancevich, J.M., Konopaske, R.dan Matteson, M. (2011). Perilaku dan Manajemen Organisasi. Jakarta: Erlangga.

Jayaweera, T. (2015). Impact of Work Environmental Factors on Job Performance, Mediating Role of Work Motivation: A Study of Hotel Sector in England. International Journal of Business and Management, 10(3), 271278.https://doi.org/10.5539/ijbm.v10n3p271

Jerry, M. L., Tjia F. T., \& Naga, N. (2012). Analisis Pengaruh Lingkungan Kerja dan Pemberian Kompensasi terhadap Kinerja Karyawan CV Mum Indonesia. Binus Business Review, 3(1), 573-586.https://doi.org/10.21512/bbr.v3i1.1344.

Mangkunegara, A.P. (2002). Manajemen Sumber Daya Manusia. Bandung: PT. Remaja Rosda Karya.

Moulana, F., Sunuharyo, B., \& Utami, H. (2017). Pengaruh Lingkungan Kerja terhadap Kinerja Karyawan melalui Variabel Mediator Motivasi Kerja (Studi pada Karyawan PT. Telkom Indonesia, Tbk Witel Jatim Selatan, Jalan A. Yani, Malang). Jurnal Administrasi Bisnis, 44(1), 178-185.

Nadia And Fathurahman, H. (2017). Relationships between Physical Working Environment, Employee Well-being, and Employee Commitment in Hospital Management. International Journal of Administrative Science \& Organization, 24(3), 140-144.

Narasuci, W., Setiawan, M., \& N. (2018). Effect of Work Environment on Lecturer Performance Mediated by Work Motivation and Job Satisfaction. Journal of Applied Management, 16(4), 645-653. https://doi.org/http://dx.doi.org/ 10.21776/ub.jam.2018. 016.04.11

Nitisemito A. (2015). Manajemen Sumber Daya Manusia. Bandung: Pustaka setia.

Putri, F. I. (2014). Hubungan Motivasi Kerja dengan Komitmen Kerja Karyawan di Balai Pendidikan dan Pelatihan Sosial. Jurnal Administrasi Pendidikan, 2(1), 220-231.

Putri, E. M., Maharani, V., Supriyanto, A.S., Mukaffi, Z. (2019). The Effect Of Work Environment On Employee Performance Through Work Discipline. International Journal Of Research - GRANTHAALAYAH 7(4), 132-140. DOI: 10.5281/Zenodo.2653144

Prawirosentono, S. (1999). Kebijakan Kinerja Karyawan. Yogyakarta: BPFE.

Robbins, S. P. (2006). Perilaku Organisasi. Jakarta: PT Indeks kelompok Gramedia.

Samson, G. N., Waiganjo, M., \& Koima, J. (2015). Effect of Workplace Environment on the Performance of Commercial Banks Employees in Nakuru Town. International Journal of Managerial Studies and Research, 3(12), 76-89. https://www.arcjournals.org/pdfs/ijmsr/v3-i12/9.pdf 
Sedarmayanti. (2009). Sumber Daya Manusia dan Produktivitas Kerja. Bandung: CV Mandar Maju.

Setiawan, R., dan Lestari, E. P. (2016). Pengaruh Budaya Organisasi, Komunikasi, Lingkungan Kerja dan Motivasi terhadap Komitmen Organisasi dalam Meningkatkan Kinerja Pegawai. Jurnal Organisasi dan Manajemen, 12(2), 169-184.

Shalahuddin, A. (2013). Pengaruh Kepemimpinan dan Lingkungan Kerja terhadap Komitmen Organisasional dan Kinerja Karyawan PT Sumber Djantin di Kalimantan Barat. Jurnal Manajemen Teori dan Terapan, 6(1), 89-104.

Sudibjo, N. \& Nasution, R. A. (2020). Work Environment, Work Motivation, and Organizational Culture in Influencing Teachers' Performance. Jurnal Pendidikan Dan Pengajaran, 53(3), 276-286

Supriyanto, A.S., Ekowati, V.M., \& Vironika, H. (2020). Linking work environment to employee performance: the mediating role of work discipline. BISMA (Bisnis dan Manajemen), 13(1), pp. 14-25. https://doi.org/10.26740/bisma.v13n1.p14-25

Supriyanto, Sani, A., and Ekowati, V.M. (2019). Riset Manajemen SDM, untuk Skripsi, Tesis dan Disertasi, dan Dilengkapi dengan Contoh Artikel Jurnal. Malang: Inteligensia Media.

Sutanto, E.M., Ratna, A. (2015). Pengaruh Komitmen Organisasional Terhadap Kinerja Karyawan Berdasarkan Karakteristik Individual. Bisma Jurnal Bisnis dan Manajemen, 9(1), 56-70

Triwahyuni, R. and Ekowati, V. M. (2017). The Effect of Employee Satisfaction on Employees Performance Trhough Organizational Commitment. Management and Economics Journal (MEC-J), 1(1), 1-12.

Wijaya, H., Susanty, E. (2017). Wijaya Pengaruh Lingkungan Kerja Terhadap Kinerja Pegawai Pada Instansi Pemerintah Daerah Kabupaten Musi Banyuasin (Studi Kasus Dinas Pertambangan Dan Energi Kabupaten Musi Banyuasin). Jurnal ecoment Global, 2(1), 40-50. 